\title{
Implementasi Metode Peta Konsep Pada Mata Pelajaran Sejarah dalam Meningkatkan Prestasi Belajar Siswa SMA
}

\author{
Nurjannah ${ }^{1}$, Sumiyati ${ }^{2}$ \\ 1,2Program Studi Pendidikan Sejarah, STKIP Yapis Dompu \\ E-mail:janahmalik50@gmail.com
}

Article History: Received: 2022-01-11 || Revised: 2022-02-01 || Published: 2022-02-11

Sejarah Artikel : Diterima: 2022-01-11 || Direvisi: 2022-02-01 || Dipublikasi: 2022-02-11

\begin{abstract}
The aim of this research is to find out if there is an increase in history learning achievement for class XI students of SMA Negeri 2 Bolo through the Concept Map Method. This type of research is Classroom Action Research (CAR). The research subject consists of several variables to be studied, namely: (1) The input variables consist of, students, learning materials, teachers and concept map methods. (2) The process variables include the stages of learning carried out by teachers and students. The things that were observed were the activities of students and teachers during the learning process using the network tree concept map method. (3) The output variable includes the final result of the learning process using the concept map network method. The data collection methods used are observation, tests, and documentation. It can be concluded from this research that learning with the application of the concept map method can improve the learning achievement of class XI students of SMA Negeri 2 Bolo in the 2021/2022 academic year. The increase in student achievement can be proven by increasing learning mastery in the first cycle, which is $42.58 \%$, and learning mastery in the second cycle, which is $71.85 \%$. Referring to the results of data analysis on the level of activity and competence of these students, the alternative hypothesis (Ha) proposed is ACCEPTED. This means that there is an increase in learning achievement by using the network tree concept map method in class XIinterested SMA Negeri 2 Bolo in the 2021/2022 academic year.
\end{abstract}

Keywords: Concept Map, History, Learning Achievement.

\begin{abstract}
Abstrak
Tujuan yang ingin dicapai dalam penelitian ini adalah untuk Mengetahui ada peningkatan prestasi belajar Sejarah bagi siswa kelas XI-peminatan SMA Negeri 2 Bolo Melalui Metode Peta Konsep. Jenis penelitian ini yaitu penelitian Tindakan Kelas (PTK). Subjek penelitian terdiri dari beberapa variabel yang akan diteliti, yaitu : (1) Variabel input terdiri atas, siswa, materi pembelajaran, guru dan metode peta konsep. (2) Variabel proses meliputi tahap-tahap pembelajaran yang dilakukan guru dan siswa. Hal-hal yang diamati yaitu aktivitas siswa maupun guru selama proses pembelajaran berlangsung dengan menggunakan metode peta konsep pohon jaringan. (3) Variabel output meliputi hasil akhir dari proses pembelajaran menggunakan metode peta konsep pohon jaringan.. Metode pengumpulan data yang digunakan ialah observasi, tes, dan dokumentasi. Dapat disimpulkan dari penelitian ini yaitu bahwa pembelajaran dengan penerapan metode peta konsep dapat meningkatkan prestasi belajar siswa kelas XI-peminatan SMA Negeri 2 Bolo Tahun pembelajaran 2021/2022. Peningkatan prestasi belajar siswa dapat dibuktikan dengan meningkatnya ketuntasan belajar pada siklus satu yaitu sebesar $42,58 \%$, dan ketuntasan belajar pada siklus dua yaitu sebesar 71,85\%. Mengacu pada hasil analisis data tentang tingkat aktivitas dan kompetensi siswa tersebut, maka hipotesis alternativ (Ha) yang diajukan DITERIMA. Artinya terdapat peningkatan prestasi belajar dengan menggunakan metode peta konsep pohon jaringan pada siswa kelas XI-peminatan SMA Negeri 2 Bolo Tahun pembelajaran 2021/2022.
\end{abstract}

Kata kunci: Peta Konsep, Sejarah, Prestasi Belajar.

\section{PENDAHULUAN}

Tujuan pendidikan Indonesia adalah membentuk manusia yang berkepribadian, mandir, maju, tangguh, cerdas, kreatif, terampil, disiplin, berety kerja, profesional, bertanggung jawab, produktif, serta sehat jasmani dan rohani ( Jalaluddin, 2014: 202) Pendidikan adalah usaha sadar dan terencana untuk mewujudkan suasana belajar dan proses pembelajaran agar peserta didik secara 
akrif mengembangkan potensi dirinya untuk memuliki kekuatan spiritual keagamaan, pengendalian diri, kepribadian, kecerdasan, akhlak mulia, serta keterampilan diperlukan dirinya, masyarakat, bangsa dan negara sesuai dengan isi Undang-Undang Republik Indonesia No. 20 Tahun 2003 tentang Sistem Pendidikan Nasional. ( Jalaluddin, 2014: 205)

Untuk mencapai tujuan pendidikan nasional seperti yang terurai diatas, diperlukan ketepatan strategi dan metode pengajaran dari seorang guru dalam menyampaikan materi pembelajaran. Menurut suryani (2012: 49) metode pembelajaran dijabarkan ke dalam teknik dan gaya pembelajaran. Dengan demikian, teknik pembelajaran dapat diatikan sebagai cara yang dilakukan seseorang dalam mengimplementasikan suatu metode secara spesifik. Tujuan kegiatan belajarmengajar tidak pernah akan tercapai selama komponen-komponen lain diabaikan. Salah satu komponen pening untuk mencapai tujuan adalah metode. Jadi metode merupakan salah satu alat untuk mencapai tujuan pembelajaran. Dengan menggunakan metode secara akurat guru akan mampu mencapai tujuan pembelajaran. Ketika tujuan pembelajaran dirumuskan agar peserta didik memiliki keterampilan tertentu, maka metode yang digunakan harus disesuaikan dengan tujuan. Artinya, bahwa metode harus menunjang tercapainya tujuan pembelajaran. Oleh karena itu, sebaiknya guru menggunakan metode yang dapat menunjang kegiatan belajar-mengajar, sehingga dapat digunakan sebagai alat yang efektif untuk mencapai tujuan pembelajaran, dalam pelajaran sejarah, diperlukan berbagai macam strategi, termasuk strategi yang belum banyak dilakukan oleh guru yaitu strategi pembelajaran dengan peta konsep (Concept Mapping). Dengan membuat peta konsep diharapkan dapat mempermudah penguasaan terhadap kompetensi pembelajaran Sejarah. Peta konsep ini juga dapat digunakan sebagai cara untuk membangun struktur pengetahuan peserta didik dalam mencapai kompetensi yang diharapkan.

Berdasarkan hasil observasi awal penulis pada bulan September 2021 di SMA Negeri 2 Bolo bahwa belum banyak guru yang menerapkan metode peta konsep bagi pembelajaran siswa kelas $\mathrm{XI}$, dan pada saat berlangsungnya proses pembelajaran terlihat bahwa siswa merasa bosan dengan cara mengajar guru yang hanya berpusat pada satu metode saja yaitu metode ceramah guru lebih mendominasi proses pembelajaran dengan informasi hanya diterima dari guru tanpa melibatkan siswa membangun pemahamannya sendiri. Padahal tinggi rendahnya pemahaman siswa dapat terlihat dari proses belajar yang sedang berlangsung atau hasil belajarnya, karena pemahaman merupakan salah satu faktor penyebab keberhasilan dalam belajar, Berdasarkan uraian di atas, penulis bertujuan untuk melakukan penelitian dengan judul "Implementasi metode peta konsep pada mata pelajaran Sejarah dalam meningkatkan prestasi belajar siswa di kelas XI-Peminatan SMA Negeri 2 Bolo tahun pembelajaran 2021/2022".

\section{METODE PENELITIAN}

Penelitian ini merupakan Penelitian Tindakan Kelas (PTK). Arikunto (2010: 57) menyatakan bahwa penelitian tindakan kelas merupakan penelitian yang dilakukan oleh guru, bekerja sama dengan peneliti di kelas atau di sekolah dengan penekanan pada penyempurnaan atau peningkatan proses dan praktis pembelajaran. Penelitian ini menggunakan rancangan Clasroom Action Research atau penelitian tindakan kelas (PTK). Seperti menurut Arikunto (2010: 74) bahwa PTK terdiri atas rangkaian empat kegiatan yang di lakukan dalam siklus berulang. Empat kegiatan utama yang ada pada setiap siklus yaitu, perencanaan (planing), pelaksanaan (Acting), pengamatan (Adserting), dan refleksi (Reflecting), PTK juga dilakukan untuk memperbaiki mutu praktik pembelajaran di kelas. PTK bertujuan untuk menemukan kelebihan dan kelemahan proses pembelajaran, sehingga dengan upaya tersebut dapat ditentukan langkah penyempurnaannya, Penelitian dilaksanakan di SMA Negeri 2 Bolo kelas XI-peminatan tahun pembelajaran 2021/2022, yang berjumlah 26 orang siswa yang terdiri atas 12 siswa laki-laki dan 14 siswa perempuan. Selanjutnya pada data yang berkaitan dengan nama atau identitas siswa akan dicantumkan dalam bentuk inisial, dengan tujuan untuk menjaga kerahasiaan data yang diperoleh dan bentuk privasi siswa, teknik pengumpulan data yang digunakan diantaranya: Observasi, Tes Evaluasi, dan Dokumentasi, dengan teknik Analisis data menggunakan, analisis data hasil observasi dan data hasil Evaluasi melalui Tes, Menurut Kunandar (2012: 127) indicator kinerja adalah suatu criteria yang digunakan untuk melihat tingkat keberhasilan dari kegiatan PTK dalam meningkatkan atau memperbaiki mutu proses pembelajaran di kelas. Purwanto (dalam Maman, 2013: 34) mengemukakan bahwa siswa dikatakan tuntas secara 
individual jika mencapai nilai 65 , sedangkan ketuntasan klasikal jika terdapat $80 \%$ siswa yang telah memperoleh nilai 65.

\section{HASIL DAN PEMBAHASAN}

\section{Rekapitulasi Prestasi Belajar Siswa Siklus I dan II}

Dari gabungan hasil nilai prestasi belajar siswa dengan menggunakan metode peta konsep pohon jaringan pada siklus 1 dan II dengan tujuan mempermudah menganalisisnya.

Berdasarkan hasil pengamatan selama proses pembelajaran menunjukkan siswa dalam mengikuti pembelajaran dengan penerapa metode peta konsep sudah menunjukkan perubahan dari siklus yang sebelumnya. Siswa sudah mulai mengerti dan paham tentang proses pembelajaran bagaimana cara mengurutkan konsep-konsep pembelajaran sehingga nilai yang diperoleh siswa pada siklus II telah menunjukkan perubahan yang signifikan dengan nilai rata-rata mencapai 74,03 dan ketuntasan klasikalnya yaitu 84,61\%. Siswa yang memperoleh nilai $\leq 65$ ada 4, siswa yang memperoleh nilai $\geq 65$ yaitu 22 orang siswa. Maka, tindakan dihentikan. Berkaitan dengan kenyataan di atas, Purwanto (dalam Maman, 2013: 15) menjelaskan bahwa siswa dinyatakan tuntas secara individual jika mencapai nilai $\geq 65$, sedangkan ketuntasan klasikal jika terdapat $80 \%$ siswa telah memperoleh $\geq 65$.

Berdasarkan nilai yang didapatkan di atas, maka analisis tersebut dapat dijabarkan sebagai berikut. Skor yang dicapai pada siklus I adalah 1570 dan skor dicapai pada siklus II adalah 1925 . Untuk mendapatkan nilai ketuntasan klasikal, maka digunakan rumus sebagai berikut: $\mathrm{KB}=\frac{N T}{T} \mathrm{X}$ $100 \% \mathrm{ST}=$ skor yang dicapai siswa yang tuntas dibagi $\mathrm{T}=$ jumlah seluruh siswa, maka skor pada siklus I memperoleh ketuntasan klasikal 42,85\% dan siklus II ketuntasan klasikal 84,61\%. Berdasarkan hasil perolehan skor tercapai dan hasil ketuntasan belajar secara klasikal, maka dapat disimpulkan bahwa hipotesis yang diajukan DITERIMA. Ini berarti bahwa penerapan metode peta konsep dapat meningkatkan prestasi belajar siswa kelas XI-Peminatan SMA Negeri 2 Bolo tahun pembelajaran 2021/2022.

\section{SIMPULAN DAN SARAN}

\section{A. Simpulan}

Berdasarkan data dan hasil analisis data, maka dapat disimpulkan bahwa pembelajaran dengan penerapan metode peta konsep dapat meningkatkan prestasi belajar siswa kelas XI-Peminatan SMA Negeri 2 Bolo tahun pembelajaran 2021/2022. Peningkatan prestasi belajar siswa dapat dibuktikan dengan meningkatnya ketuntasan belajar pada siklus satu yaitu sebesar 42,58\%, dan ketuntasan belajar pada siklus dua yaitu sebesar 71,85\%. Mengacu pada hasil analisis data tentang tingkat aktivitas dan kompetensi siswa tersebut, maka hipotesis alternativ (Ha) yang diajukan DITERIMA. Artinya terdapat peningkatan prestasi belajar dengan menggunakan metode peta konsep pohon jaringan pada siswa kelas XI-Peminatan SMA Negeri 2 Bolo tahun pembelajaran $2021 / 2022$.

\section{B. Saran}

Berikut disajikan beberapa saran yang dapat mendukung penelitian berikutnya, antara lain:

1. Sebaiknya guru menciptakan suasana belajar yang santai, aktif dan ceria, sehingga tidak membuat tegang atau membuat siswa terbebani serta guru harus mampu membangkitkan minat belajar siswa.

2. Bagi siswa hendak lebih mengembangkan inisiatif dan keberanian dalam menyampaikan pendapat dalam proses pembelajaran untuk menambah pengetahuan sehingga dapat meningkatkan minat belajar

\section{DAFTAR RUJUKAN}

Aman. 2012. Model Evaluasi Pembelajaran Sejarah. Yogyakarta: Ombak

Arikunto, Suharsimi. 2010. Prosdur penelitian suatu pendekatan praktik. Jakarta: Rineka Cipta

Dan, A., \& Yang, F. (2018). Study About Studen Learning Achievement Aspect And factors Affecting. Jurnal Komunikasi Pendidikan, 2(2), 115-123. 
Hamid,Adb Rahman \& madjid, Muhammad Saleh.2011. Pengantar Ilmu Sejarah. Yogyakarta: Ombak

Jalaluddin dan Idi, Abdullah. 2014. Filsafat Pendidikan "manusia, filsafat, dan pendidikan edisi revisi" Jakarta: Raja Grafindon Persada

Luki Yunita, Ahmad Sofyan, S. A. (2014). Pemanfaatan Peta Konsep (Consept Mapping) Untuk Meningkatkan Pemahaman Siswa Tentang Senyawa Hidrokarbon. EDUSAINS, VI, 1-8.

Kunandar. 2012. Langkah Mudah Penelitian Tindakan Kelas Sebagai Pengembangan Profesi Guru. Jakarta: Rajawali Media

Maman, 2013. Meningkatkan Out Cames Pendidikan di Kawasan Pendalaman Melalui Manajemen Berbasis Masalah. Karya ilmiah Disajikan dalam Lomba Pemilihan Kepala Sekolah Berprestasi/berdikari Tingkat Propinsi NTB, Mataram, 9-11 Juni.

Nursyaidah. (2014). Faktor-faktor Yang mempengaruhi Belajar Peserta Didik. Oleh. Forum Poedagogik Edisi Khusus Juli-Desember 2014, 70-79

Khatimah, H. (2021). Pengaruh Penggunaan Multimedia Terhadap Minat Belajar IPS Siswa SMK. Ainara Journal Uurnal Penelitian Dan PKM Bidang Ilmu Pendidikan), 2(3), 222-229. https://doi.org/10.54371/ainj.v2i3.85

Minartin. (2018). PENERAPAN MODEL PEMBELAJARAN EXAMPLE NON EXAMPLE UNTUK MENINGKATKAN HASIL BELAJAR SISWA KELAS IV SDN RANDUAGUNG 01 PADA PELAJARAN IPS TAHUN. Jurnal PTK Dan Pendidikan, 3(2), 35-44.

Nursyaidah. (2014). FAKTOR-FAKTOR YANG MEMPENGARUHI BELAJAR PESERTA DIDIK Oleh. Forum Poedagogik Edisi Khusus Juli-Desember 2014, Oleh, 70-79.

Riduwan. 2010. Dasar-dasar Statistika. Bandung: Alfabeta.

Shoimin, Aris. 2014. 68 Model Pembelajaran Inovatif dalam kurikulum 2013.Yogyakarta: AR-RUZZ MEDIA

Suryani, Nunuk dan Agung, Leo. 2012. strategi belajar mengajar. Yogyakarta: Ombak

Susanto, H. \& H. A. (2019). MEDIA PEMBELAJARAN SEJARAH ERA TEKNOLOGI INFORMASI (KONSEP DASAR, PRINSIP APLIKATIF, DAN PERANCANGANNYA) (Bambang Subiyakto (ed.); pertama, 2). Program Studi Pendidikan Sejarah Fakultas Keguruan dan Ilmu Pendidikan Universitas Lambung Mangkurat.

Sumiyati, S., Yusnarti, M., \& Khatimah, H. (2021). Bahan Ajar Sejarah Maritim \&quot;Wadu Tanda Rahi\&quot;. Ainara Journal (Jurnal Penelitian Dan PKM Bidang Ilmu Pendidikan), 2(4), 143-149. https://doi.org/10.54371/ainj.v2i4.96

Sumiyati, S., \& Khatimah, H. (2021). Penggunaan Objek Sejarah Dompu Sebagai Sumber Belajar di SMA Negeri 2 Woja. Ainara Journal (Jurnal Penelitian Dan PKM Bidang Ilmu Pendidikan), 2(3), 206211. https://doi.org/10.54371/ainj.v2i3.82 